\title{
Assessing gaseous pollutants and air quality in some areas of Kano metropolis, Kano, Nigeria
}

\author{
M. D. Garba \& M. S. Yunusa \\ Federal College of Education (Tech), Bichi, Nigeria
}

\begin{abstract}
This study assesses the air quality of some areas in Kano metropolis. It was conducted for a period of two months in 2013 through direct field measurement of gaseous pollutant concentration in ten different locations using mobile gas censors. The air pollutants measured includes carbon monoxide (CO), sulphur dioxide $\left(\mathrm{SO}_{2}\right)$, nitrogen dioxide $\left(\mathrm{NO}_{2}\right)$, hydrogen sulphide $\left(\mathrm{H}_{2} \mathrm{~S}\right)$, methane $\left(\mathrm{CH}_{4}\right)$ and ammonia $\left(\mathrm{NH}_{3}\right)$. In some areas, the study indicated higher concentrations of $\mathrm{CO}, \mathrm{NO}_{2}$ and $\mathrm{H}_{2} \mathrm{~S}$ above the air quality standard stipulated by the Federal Environmental Protection Agency (FEPA). This implies that, the air quality of the areas is not within the safe limits. Thus, the consequences of the pollutants to public health were discussed. The study recommends the implementation of tighter vehicular emission regulations and provision of more parking spaces along the higher traffic roads of the metropolis, among others.
\end{abstract}

Keywords: gaseous pollutants, air quality, areas, Kano, Metropolis, Nigeria.

\section{Introduction}

Air is a mixture of gases, comprising $21 \%$ oxygen, $78 \%$ nitrogen and a trace amount of rare gases. It is one of the most essential requirements for the existence of living organisms. But industrial development which provides humanity with materials for social benefits also introduces many unwanted substances to the air. Some of these have effects on the environment and life. Hence, the environment upon which our life is dependent has fallen a victim of pollution (Agrawal et al. [1]).

Pollution is the introduction of contaminants into the environment that causes adverse change. The contaminants/pollutants can take the form of solid particles, liquid droplets or gases. Air pollutants are substances in the air that can have an 
adverse effect on humans and the ecosystem. Some of these include carbon monoxide (CO), sulphur dioxide $\left(\mathrm{SO}_{2}\right)$, nitrogen oxide $(\mathrm{NO})$, hydrogen sulphide $\left(\mathrm{H}_{2} \mathrm{~S}\right)$, hydrocarbon $(\mathrm{CH})$ and many others. Most of these are released as a product of incomplete combustion of fuel or dumping of waste resulting from human activities. But motor vehicles produce more air pollutants than any other single human activity [2-4].

These pollutants are produced in countries that depend heavily on fossil fuel whether in running vehicle, power system or heating appliances. The chief source of Carbon monoxide and Nitrogen dioxide in urban cities are the motor vehicle (Najjar [3]) and the levels of pollutants in the air are rapidly increasing in both urban and rural areas of many megacities of the developing world (Agrawal et al. [1]). Increase in number of motor vehicles, power generators, domestic fuel use, is not the only factors contributing to the increase. Other miscellaneous activities performed by man, also help in progressive degradation of air quality (Ashmore [5]).

Nigeria like any other developing country, is facing a challenge of automobiles increase, reliance on powered generators for commercial and domestic energy supply, uncontrolled incineration of waste, more traffic density on ill-planned roads, use of dirty fuels, poor industrial zoning and absence of or inadequate environmental regulations. These aggravate the bad urban air quality (Uduma and Jimoh [6]). Therefore, as people performed their activities outdoor in Nigeria, the effect of air pollution due to automobile emission must be considered.

Kano is one of the megacities in West Africa, has a population of 9,383,682 (Muktar et al. [7]). The metropolis is facing challenges of air quality management due to indiscriminate burning of refuse and high traffic density in roads. Also most of the automobiles running/shuttling within the city are old, poorly maintained local buses, taxis and tricycles [6]. Their emission depends largely on the fuel type (petrol or diesel) and the state of the vehicle engines. Similarly, the epileptic power supply has forced small and medium scale industries, shops owners to rely on petrol and diesel generators for power supply, thereby increasing pollution. Also, poor town planning and increase in percapital vehicle ownership has contributed in changing the features of Kano air quality, which Uduma and Jimoh [6] opined is changing from typical fire wood and/or fossil fuel combustion to a complex pollution case.

Much research [8-11] has reported air pollution studies in many megacities of Nigeria, but little reports are on Kano metropolis. Therefore, there is the need for more regular researches on air quality so as to safe guard those who earn their daily bread along traffic roads/areas. Hence, the need for this study.

\section{Materials and method}

\subsection{The study area}

Kano metropolis is the central part of Kano states - Nigeria (fig. 1). It is located in the North-Western Nigeria and most populous state of the Federation. Kano 
metropolis lies in the central part of Kano between latitude $11^{\circ} 25^{\prime} \mathrm{N}$ to $12^{\circ} 47^{\prime} \mathrm{N}$ and longitude $8^{\circ} 22^{\prime} \mathrm{E}$ to $8^{\circ} 39^{\prime} \mathrm{E}$. The area is made up of eight Local Governments. They include Kano Municipal, Fagge, Dala, Gwale, Tarauni, Nassarawa, Ungogo and Kumbotso with a population of 2,828,861 people (Bello et al. [11]). Kano is referred to as the centre of commerce due to its long flourishing marketing activities which dominated the economic activities of the indigenes. It is one of the oldest but growing and densely populated cities in Nigeria.

The rapid urban growth of Kano metropolis is attributed to migration of people from rural areas, either for labour or commercial activities, being the seat of government and centre of industry, commerce and education.

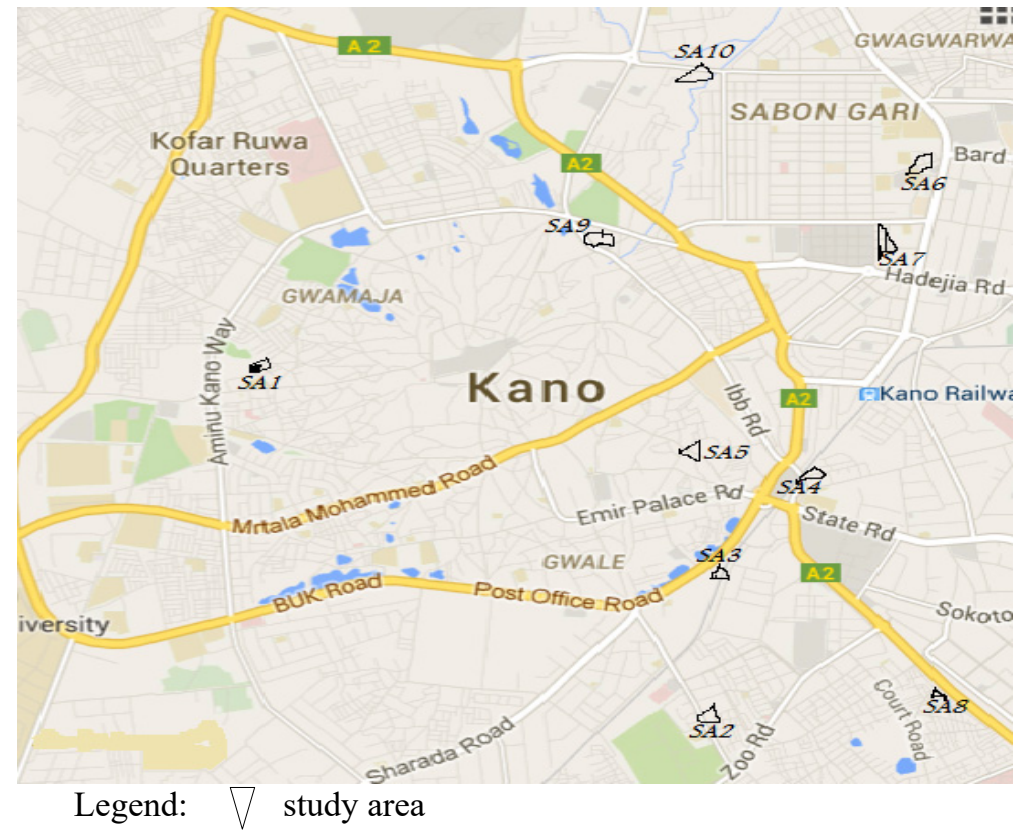

Figure 1: Map of Kano metropolis showing the study areas. (Source: 2015 Google map data, modified.)

Ten study areas (SA) within the metropolis were selected for the study as shown in figure 1. These includes Aminu Kano (SA1); Zoo Road (SA2); D/Agundi (SA3); K/Nasarawa (SA4); R/market (SA5); S/Abacha (SA6); Ibo Road (SA7); Court Road (SA8); K/Mazugal (SA9) and Zungeru Road (SA10). High traffic densities, human population and their activities within each area were considered in the selection.

Field measurement of air pollutants such as $\mathrm{CO}, \mathrm{SO}_{2}, \mathrm{NO}_{2}, \mathrm{H}_{2} \mathrm{~S}$, and $\mathrm{CH}_{4}$ were carried out using mobile gas sensors manufactured by Crown Detection Instrument Ltd. The measurements were conducted for a period of 2 months (March-April, 2013) in the morning (7:00-12:00am) and evening (4:00- 
6:00pm). The raw data obtained was analyzed using descriptive statistic (mean), which was used for the distribution pattern charts (figures 2-6).

\section{Results and discussion}

The mean concentrations of the pollutants measured are as shown in Table 1. It shows the variation pattern for each pollutant measured across the study areas. The variation of carbon monoxide across the areas is as shown in fig. 2 . Its concentration ranged from $3.50-6.34 \mathrm{ppm}$ in the morning and 5.33-21.84ppm in the evening. In all the areas, except at SA5 (where the concentration is 21.84ppm) the values are within the Nigerian Air quality standard which stipulates a range of 10-20ppm for an 8-hour range time (FEPA [12]).

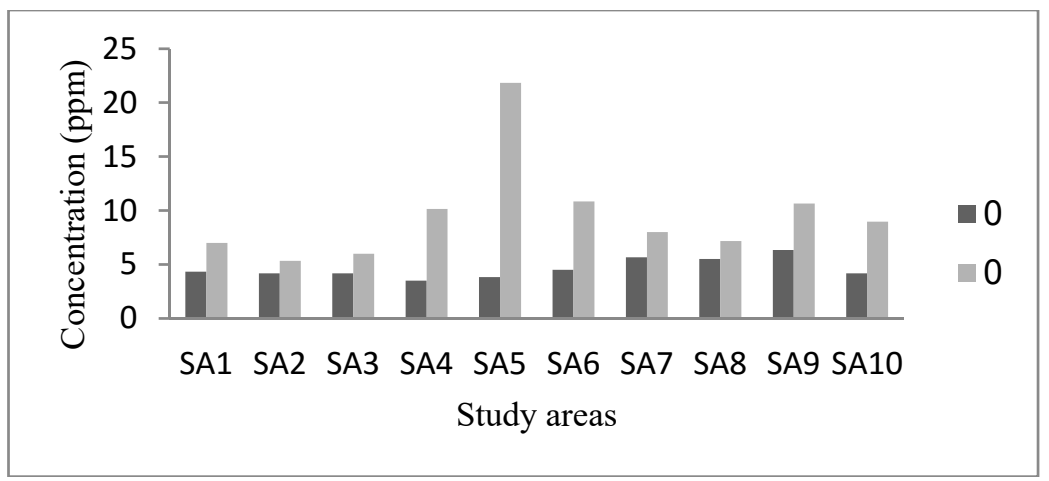

Figure 2: Variation of carbon monoxide concentration across the areas.

The higher concentration observed at SA5, may be attributed to some factors such as transportation-related emission from automobiles and stationary sources. Because the area, apart from being a local market with many business transactions, it's also serving as bus-stop for commercial vehicles along the road. The concentration observed is higher than $6.50-14.33 \mathrm{ppm}$ reported by Okunola et al. [9] in 2010, but lower than 130ppm reported in Port-Hercourt metropolis (Augustine [8]) and 233-317ppm observed in three cities of Nigeria; Lagos, Ibadan and Ado-Ekiti (Koku and Osuntogun [13]).

Sulphur dioxide measured across the study areas showed a mean concentration from $0.00-0.03 \mathrm{ppm}$ in the morning and $0.00-0.25 \mathrm{ppm}$ in the evening. The distribution pattern figure 3 shows higher concentration of $\mathrm{SO}_{2}$ at $\mathrm{SA1}$. But the level is within the range $(0.01-0.50 \mathrm{ppm})$ recommended [12]. Thus, the observed lower concentration of $\mathrm{SO}_{2}$ in Kano metropolis may probably be due to the banning of commercial motorcycle, improve sanitation measures and decongestion of roads/traffic by Kano State Road Traffic Agency (KAROTA). There is also a reduction in $\mathrm{SO}_{2}$ pollution when compared with 25.0-29.50ppm reported in 2010 in Kano by Ayodele and Abubakar [10]. Also lower than 1.00- 


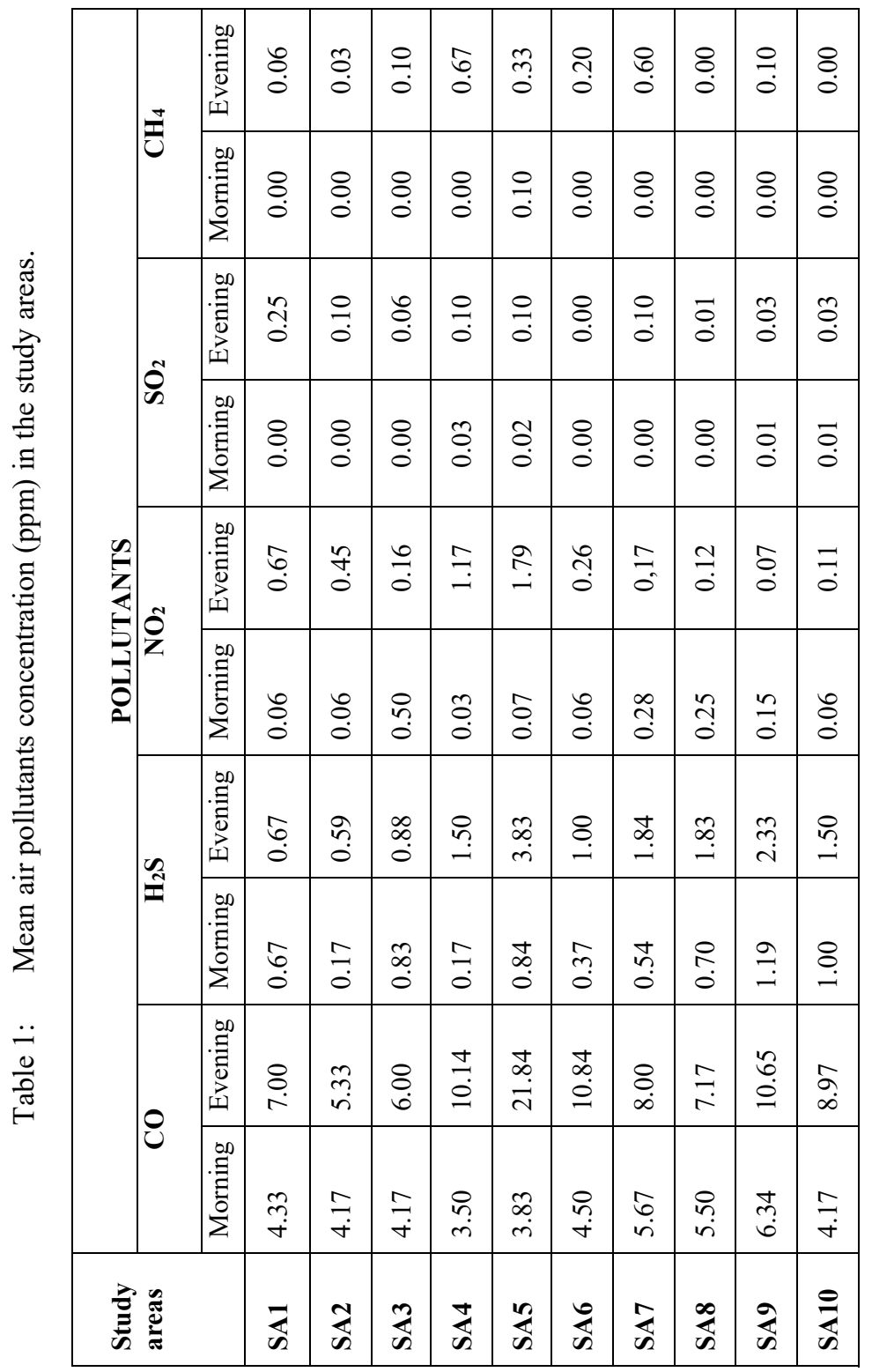




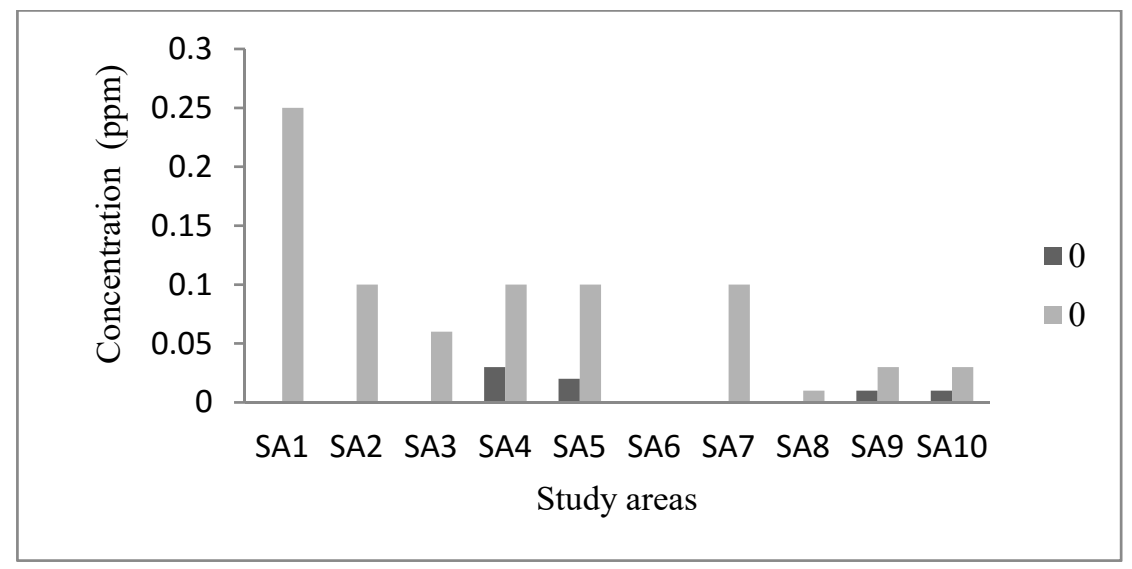

Figure 3: Variation of $\mathrm{SO}_{2}$ concentration across the areas.

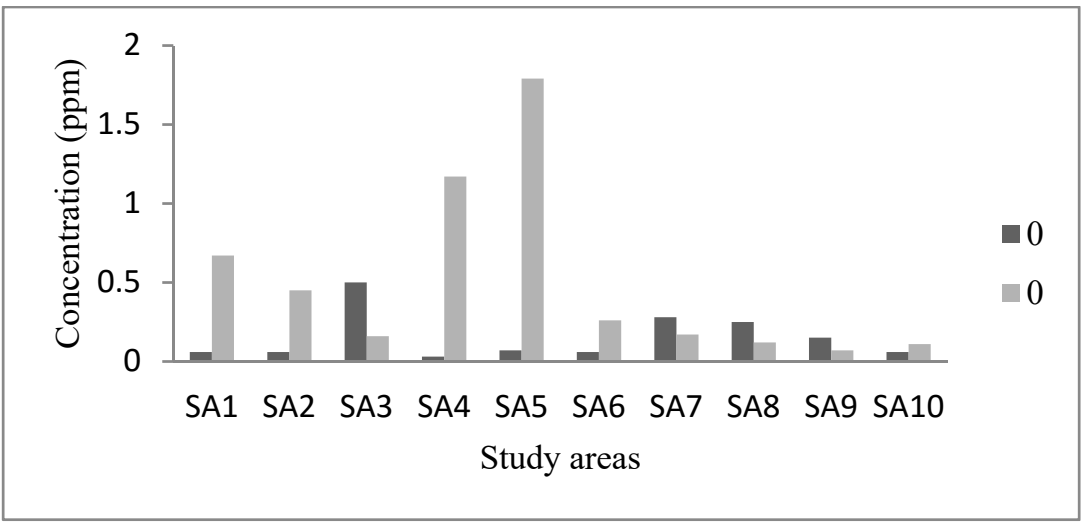

Figure 4: Variation of $\mathrm{NO}_{2}$ concentration across the areas.

1.8 ppm reported [8] in Port Harcourt metropolis. Therefore, Kano metropolis air quality is within the safe limit of sulphur IV oxide.

The concentration of Nitrogen dioxide across the study areas revealed higher values in the evening (Table 1). Similar to $\mathrm{CO}$, highest concentration was observed at $\mathrm{SA}_{5}$ (fig. 4). The mean concentration were higher than 0.14-1.09 ppm reported in 2010 [9] and lower than 35-105ppm observed in Athens, Greece (Kalabokas et al. [14]). But quite high when compared with the 0.04-0.06 ppm recommended [12] limits in Nigeria.

Kano metropolis, being a business area, is characterized by high flow of traffic especially in the evening rush. The scenario leads vehicles emitting gases depending on the type of fuel used, type and age of vehicles. These coupled with private and commercial generators which are rampant due to erratic power supply could be responsible for the observed high concentration of nitrogen 
dioxide. Other processes such as refuse burning, household used of coal for cooking and open incinerations could also be attributed for the high concentrations observed.

The mean concentration of hydrogen sulphide is as shown in Table 1. The concentrations ranged from $0.17-3.83 \mathrm{ppm}$ across the area (fig. 5). As observed in $\mathrm{CO}$ and $\mathrm{NO}_{2}$ distribution patterns, $\mathrm{H}_{2} \mathrm{~S}$ was also high in $\mathrm{SA}_{5}$. This could be attributed to the characteristics of the areas as reported, being a bus stop for most intra-city buses, taxies and tricycles and a market, trading in all sort of substances including food stuffs. The gaseous emission generated from these substances could be responsible for the high hydrogen sulphide.

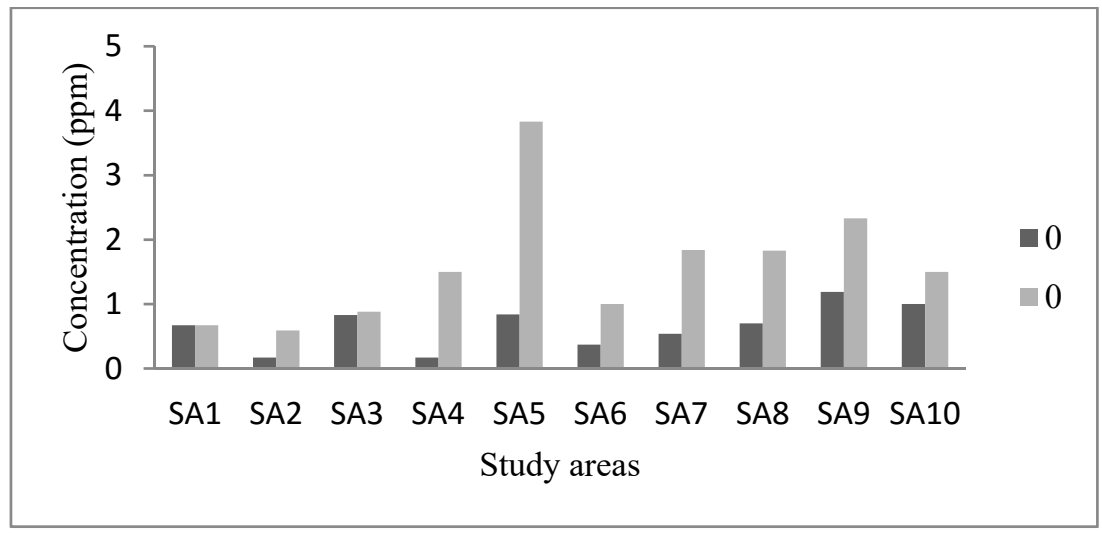

Figure 5: Variation of $\mathrm{H}_{2} \mathrm{~S}$ concentration across the areas.

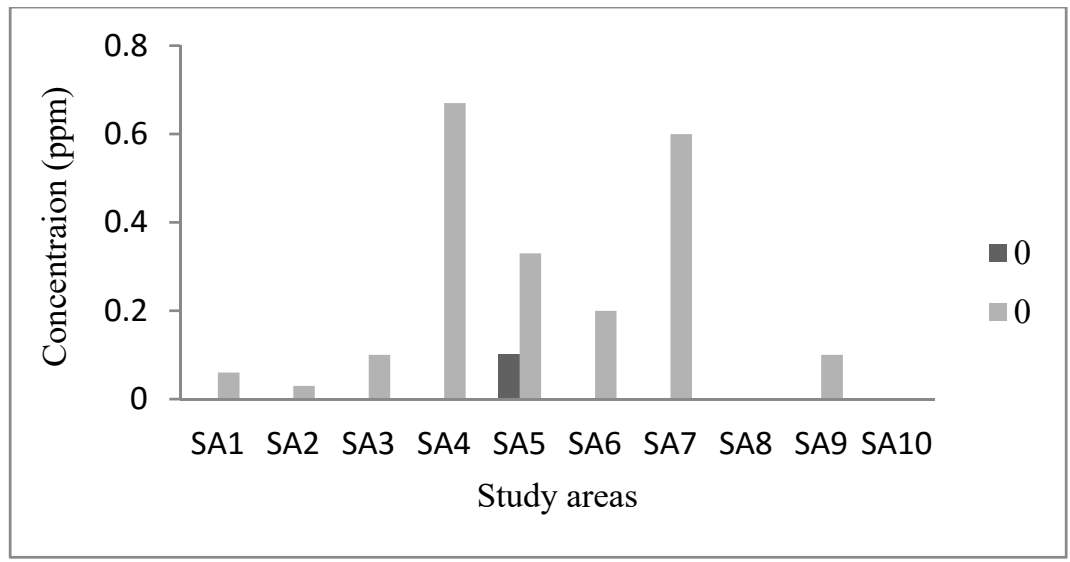

Figure 6: Variation of $\mathrm{CH}_{4}$ concentration across the areas.

The distribution variation of methane ranged from $0.00-0.67 \mathrm{ppm}$ across the areas (fig. 6). With high value obtained at $\mathrm{SA}_{4}$. Similar to all the pollutants, it shows high concentration only in the evening. The concentration is not high 
enough to cause any serious problem (Millar [15]). The mean concentration observed is lower than $0.71 \mathrm{ppm}$ and $0.64 \mathrm{ppm}$ reported in Hotoro and Challawa, Kano (Ayodele and Emmanuel [16]).

The observed methane concentration in the study may be due to the anaerobic decay of plants, animal wastes, and/or burning of natural gas. As natural gas, is used as domestic and industrial fuel in Nigeria (Hassan and Abdullahi [17]).

The mean temperature variation across the areas also ranged from 27.1$33.9^{\circ} \mathrm{C}$ in the morning and $36.2-39.1^{\circ} \mathrm{C}$ in the evening hours. This indicates an increase in temperature in the evening hours, which is also corresponding to pollutants increase in all the areas.

Generally, the distribution pattern of the pollutants studied across the areas as shown in figs 2-6 are evident that the concentrations are mostly from the same source. The highest concentration was found in location/area where automobile exhaust emissions are higher and in high traffic hold up areas. Concentration of $\mathrm{CO}, \mathrm{NO}_{2}$ and $\mathrm{H}_{2} \mathrm{~S}$ are higher in the evening across the areas, which could be due to high flow of traffic during the evening rush hours.

Across the areas, except at $\mathrm{SA} 5$, lower concentration for $\mathrm{CO}, \mathrm{H}_{2} \mathrm{~S}, \mathrm{SO}_{2}$ and $\mathrm{CH}_{4}$ were recorded. High traffic volume could be responsible for the high concentration at SA5 as stated above. Being the area is a junction, for buses, taxies and tricycle leading to Kwambai, Kurmi market, Nassarawa, Emirs' palace, part of old city Yola and international market (kantin-kwari). The observed traffic is common in the area. However, the observed high $\mathrm{NO}_{2}$ concentration across the areas may be attributed to different processes such as rampant refuse dumpsites burning, and open incineration in addition to vehicular and generators that uses gasoline/or diesel.

Though, only one area recorded high concentration of pollutants. But it is important to check the pollution sources in all the areas including those recorded lower values, because gaseous pollutants concentrations are very critical in terms of exposure index. The pollutants significantly affect the chemistry of the atmosphere $[17,18]$.

\section{Conclusions}

Clear air is the most essential requirement to sustain life. The analysis conducted showed various degrees of $\mathrm{CO}, \mathrm{SO}_{2}, \mathrm{NO}_{2}, \mathrm{H}_{2} \mathrm{~S}$ and $\mathrm{CH}_{4}$ presence in the ambient air of Kano metropolis. High concentrations of these gases were detected in Rimi market, which is one of the most traffic areas in the metropolis. The high concentration shows that safety standards for road transport are inadequate in the area. It is therefore imperative to put in place all measures that will avoid continuous increase of those pollutants for improve air quality. The paper therefore recommended that (i) Air quality measures should be strengthen through enforcing tighter vehicular emission regulations. (ii) More parking spaces should be provided away from the roads and market premises in order to reduce traffic density. (iii) Integrated environmental considerations in urban planning including locating offices, and commercial areas convenient for pedestrians and bicyclists in order to reduce the need for motorized transport, 
preventing traffic congestion and locating non-residential functions around urban highways as [19, 20] suggested. (iv) Encouraging tree planting and avoiding deforestation as trees/plants serve as natural process of air purification by photosynthesis. (v) Public enlightenment to educate people on proper disposal measures and the consequences of improper act on the environment.

\section{Acknowledgement}

The authors appreciate the support of Alh. Baba of Pollution Control Unit, Ministry of Environment, Kano state, for his assistance especially in the field work.

\section{References}

[1] Agrawal, M. Richer, R, Madhu, R., and Agrawal, S.B. Gaseous air pollutants: a review on current and future trends of emission and impact on agriculture. Scientific research, 55, pp. 77-102, 2011

[2] Garret, T.K, Newton, K., The motor vehicle, New York, pp. 24-29, 2001.

[3] Najjar, Y.S.H., Gaseous pollutants formation and their harmful effect on health and environment.Innovative energy policies, I, pp. 42-49, 2011.

[4] Suleiman, I.L., Examining air pollution and control, measures in urban centre of Nigeria. Environmental engineering and measurement, 4(6), pp. 621-628, 2013.

[5] Ashmore, M.R, Assessing the future global impacts of ozone on vegetation. Plant, cell and environments, 28, pp. 949-964, 2005.

[6] Uduma, A.U Jimoh, W.L.O, High incidence of asthma, bronchitis, pneumonia and sinusitis in Kano state, North West Nigeria during Sahara Dust events. Environment, energy and power research. I(8), pp. 174-185, 2013.

[7] Muktar, M.D., Indabawa, I.I., and Imam. T.S. Public health implications of sewage ponds in Kano metropolis, Nigeria. Food, Agriculture and Environment, 8(2), pp. 25-31, 2010.

[8] Augustine, C., Impact of air pollution on the environment in Port Harcourt, Nigeria. Environment science and water resources, (3), pp. 46$51,2012$.

[9] Okunola, O.J, Uzairu, A, Gimba, C.E and Wdukwe, G.I., Assessment of gaseous pollutants along high traffic roads in Kano, Nigeria. Environments and sustainability, I(1), pp. 1-55, 2012.

[10] Ayodele, J.T and Abubakar, F., Sulphur dioxide as indoor pollutant in Kano Municipal Kano-Nigeria, Environmental Chemistry and Ecotoxicology, 2(1), pp. 9-13, 2010.

[11] Bello, Y.A., Adzandeh, E.A and Fabiyi, O.O. Statistical analysis of urban growth in Kano metropolis, Environmental monitoring and analysis, 2(1), pp. 50-56, 2014. 
[12] Federal Environmental Protection Agency (FEPA), Guidelines and standards for environmental pollution control in Nigeria. Agency press, Abuja, Nigeria.

[13] Koku, C.A and Osuntogun, B.A., Environmental impacts of road transportation in south-western states of Nigeria. Applied sciences 7(16). pp. 56-60, 2007

[14] Kalabokas, P.O., Viras, L.G. and Repapis, C., Analysis of the 11-years record (1987-1997) of air pollution measurements in Athens Greece, part I: primary air pollutants, Global Nest, (I) pp. 157-167, 1999.

[15] Millar, G.T., Living in the environment, an introduction to environmental sciences. Belmont: Wadsworth, 1990.

[16] Ayodele, J.T and Emmanuel, B., Methane in Kano-Nigeria atmosphere. Caspian J. Env. Sci. 5(2), pp. 133-141, 2007.

[17] Hassan, S.M., Abdullahi, M.E., Evaluation of pollutants in ambient air: a case study of Abuja-Nigeria. Scientific and Research publication, 12(12), pp. 1-5, 2012.

[18] WHO, Exposure to air pollution: a major public health concern. Geneva, World Health Organization. http://www.who.int/mediacentre/factosheets /.fs292/en/index.htm

[19] Krzyzanowske, M., Health effects of transport related air pollutions: summary for policy makers. Copenhagen, WHO regional office. http://www.euro.who.int/data/assets/poll file/0006/74715/E86650.pdf

[20] Ibrahim, A.M, Paying for the priceless: the consequences of air and noise pollution in some commercial areas of Kano metropolis. Humanities and social science invention, 3(6), pp. 17-21, 2014. 